\title{
Effects of L-arginine oral supplements in pregnant spontaneously hypertensive rats ${ }^{1}$
}

\author{
Efeitos da oferta oral de L-arginina em ratas prenhas espontaneamente hipertensas
}

\author{
José Ricardo Sousa Ayres de Moura², Nelson Sass ${ }^{3}$, Sérgio Botelho Guimarães ${ }^{4}$, Paulo Roberto Leitão de Vasconcelos 5 , \\ Rosiane Mattar ${ }^{6}$, Luis Kulay $\mathbf{J r}^{7}$ \\ 1. Central Research Laboratory (CEDEME), Post-graduation Program in Obstetrics (Doctorate), Federal University of São Paulo (UNIFESP). Brazil. \\ 2. Master in Surgery, Post-graduate fellow (Doctorate), UNIFESP. Brazil. \\ 3. Associate Professor of Obstetrics, UNIFESP. Brazil. \\ 4. Associate Professor of Surgery, Federal University of Ceará (UFC). Brazil. \\ 5. Associate Professor of Surgery, Coordinator, Post-graduation Program in Surgery, UFC. Brazil. \\ 6. Associate Professor of Obstetrics, Coordinator, Post-graduation Program in Obstetrics, UNIFESP, Brazil. \\ 7. Full Professor of Obstetrics, UNIFESP. Brazil.
}

\begin{abstract}
Purpose: To evaluate the effects of L-arginine oral supplementation in spontaneously hypertensive pregnant rats (SHR). Methods: Thirty SHR and ten Wistar-EPM-1 virgin female rats were used in the study. Before randomization, females were caged with males of the same strain (3:1). Pregnancy was confirmed by sperm-positive vaginal smear (Day 0). Wistar-EPM1 rats served as counterpart control (C-1). SHR rats were randomized in 4 groups $(n=10)$ : Group Control 2, non-treated rats; Group L-Arginine treated with L-arginine 2\%; Group Alpha-methyldopa treated with Alpha-methyldopa 33mg/Kg; Group L-Arginine+Alpha-methyldopa treated with L-arginine 2\%+Alpha-methyldopa 33mg/Kg. L-arginine $2 \%$ solution was offered ad libitum in drinking water and Alpha-methyldopa was administered by gavage twice a day during the length of pregnancy (20 days). Blood pressure was measured by tailcuff plethysmography on days 0 and 20. Body weight was measured on days 0, 10 and 20. Results were expressed as mean \pm SD (Standard Deviation). One-Way ANOVA/Tukey (or KruskalWallis/Dunn, as appropriate) was used for group comparisons. Statistical significance was accepted as $\mathrm{p}<0.05$. Results: There was no significant weight gain in isolated L-arginine treated SHR. Mean blood pressure decreased in L-argininetreated SLR compared with untreated-SHR rats. Conclusion: L-arginine oral supplementation reduces blood pressure in spontaneously hypertensive rats during pregnancy.
\end{abstract}

Key words: Arginine. Pregnancy, Animal. Animals, Outbred Strains. Rats.

\section{RESUMO}

Objetivo: Avaliar os efeitos da oferta oral de L-arginina em ratas prenhas espontaneamente hipertensivas (SHR). Métodos: 30 SHR e 10 Wistar-EPM-1 ratas virgens foram utilizadas no estudo. Antes da distribuição, as fêmeas foram acasaladas com machos da mesma linhagem (3:1); a prenhez foi confirmada pela presença de espermatozóides no esfregaço vaginal. As ratas Wistar-EPM-1 foram utilizadas como controles. As ratas SHR foram aleatoriamente distribuídas em 4 grupos ( $n=10)$ : Grupo Controle-2, não-tratado; Grupo L-Arginina, tratado com L-arginina; Grupo Alfa-metildopa, tratado com alfametildopa; Grupo L-Arginina+Alfa-metildopa, tratado com arginina+Alfa-metildopa. L-arginina (2\%) foi oferecida ad libitum na água de beber e a Alfa-metildopa (33 mg/Kg) foi administrada por gavagem, duas vezes ao dia, durante toda a prenhez (20 dias). Aferição da pressão arterial (PA) foi realizada por pletismografia da cauda, nos dias 0 e 20 e dos pesos nos dias 0-10-20. Resultados foram expressos como média \pm DP (Desvio Padrão). Testes estatísticos apropriados (ANOVA unidirecional/Tukey ou Kruskal-Walli/Dunn) foram utilizados para comparações intergrupais. $\mathrm{P}<0,05$ foi considerado significante. Resultados: Não houve ganho de peso significante nas ratas tratadas com L-arginina. A PA média diminuiu no Grupo L-Arginina comparado ao Grupo Controle-2. Conclusão: A oferta oral de L-arginina reduz a PA em ratas SBP durante a prenhez.

Descritores: Arginina. Prenhez. Animais de Cepas não Consangüíneas. Ratos.

\section{Introduction}

Hypertensive diseases are known to occur during pregnancy. Moderate hypertension tends to occur at the end of the pregnancy and does not represent a serious harass to life. However, severe hypertension or preeclampsia do represent a serious threat to the life of pregnant women ${ }^{1}$. Spontaneous hypertensive rats (SHR) are a genetic model of hypertension widely used in medical research because of the features they share with idiopathic hypertension in humans ${ }^{2}$. Experimental models utilizing SHR have been used to study the effects of different drugs in pregnant rats ${ }^{3,4}$. 
However, the behavior of blood pressure during pregnancy has been a matter of controversy in the literature in this animal model. Thus, no effects of pregnancy on pressure levels ${ }^{5,6}$ or any fall in pressure level during the last days of pregnancy have been reported ${ }^{7-11}$. Methyldopa is one of the most early and the most often used drug in pregnancyinduced hypertension. It works by relaxing the blood vessels so that blood can flow more easily through the body ${ }^{12}$. Recent studies have demonstrated that perinatal supplementation of nitric oxide (NO) substrate results in persistent reduction of systolic blood pressure in $\mathrm{SHR}^{4}$. LArginine is a precursor of polyamine, nitric oxide, creatine, and agmatine (guanidine, decarboxylated arginine), and is essential for the differentiation and proliferation of blood cells, although the precise biological role of L-arginine is unclear $^{13}$. As NO substrates given during pregnancy are able to induce a persistent reduction in systolic blood pressure (SBP) in $\mathrm{SHR}^{4}$, oral supplementation of L-arginine to hypertensive pregnant rats could be beneficial in reducing SBP in these animals. Hence, this study was aimed at studying the effects of L-arginine oral supplements in pregnant spontaneously hypertensive rats.

\section{Methods}

Thirty spontaneously hypertensive rats (SHR) and ten Wistar-EPM-1 virgin female rats (150-200 g, average age 90 days) obtained from the UNIFESP small animal facility, were used in this study. All rat procedures and handling were in compliance with the Federal University of São Paulo ethical guidelines for handling and care of experimental animals and the Council for International Organization of Medical Sciences (CIOMS) ethical code for animal experimentation ${ }^{14}$. All animals were of the same breed and were raised in controlled environment for research use only. The animals were housed five per cage in a room with temperature maintained at $22^{\circ} \mathrm{C} \pm 1^{\circ} \mathrm{C}$ and with a 12 -hour-light/12-hourdark cycle. All animals had free access to food and water throughout the study. For breeding, females were caged with males of the same strain (ratio 3:1), and vaginal smears were checked each morning for the presence of spermatozoa. Pregnancy was confirmed by sperm-positive vaginal smear (Day 0). Subsequently, SHR rats were randomized in 4 groups $(n=10)$ : Group Control 2 (SHR_C2), consisting of 10 nontreated rats; Group L-Arginine (SHR_Arg), consisting of 10 rats treated with L-arginine $2 \%$ solution offered ad libitum in drinking water during the length of pregnancy (20 days); Group Alpha-methyldopa (SHR_MD) consisting of 10 rats treated with Alpha-methyldopa, 33mg/Kg dissolved in drinking water $2.0 \mathrm{ml}$ and administered by gavage twice a day (7 and 19 h); Group L-Arginine+Alpha-methyldopa (SHR_A+MD) consisting of 10 rats treated with L-arginine $2 \%$ solution offered ad libitum in drinking water and Alphamethyldopa administered by gavage twice a day (7 and 19 h). Wistar-EPM-1 rats (Group Control 1 - W-EPM1_C1) served as non-hypertensive counterpart control.

\section{Blood pressure and body weight measurement}

Systolic blood pressure was measured by tailcuff plethysmography on days 0 and 20. Each blood pressure value reported was the mean of five determinations that were taken during the same session. A level of $150 \mathrm{mmHg}$ or higher was considered to be hypertension ${ }^{2}$. Body weight was evaluated on days 0,10 , and 20 of pregnancy.

\section{Statistical analysis}

Results were expressed as mean \pm SD (Standard Deviation). One-Way ANOVA/Tukey (or Kruskal-Wallis/ Dunn, as appropriate) was used for group comparisons. Statistical significance was accepted as $\mathrm{p}<0.05$.

\section{Results}

\section{Blood pressure}

Figures 1-3 depict rat's systolic blood pressure (SBP), diastolic blood pressure (DBP) and mean blood pressure (MBP) profiles, respectively.

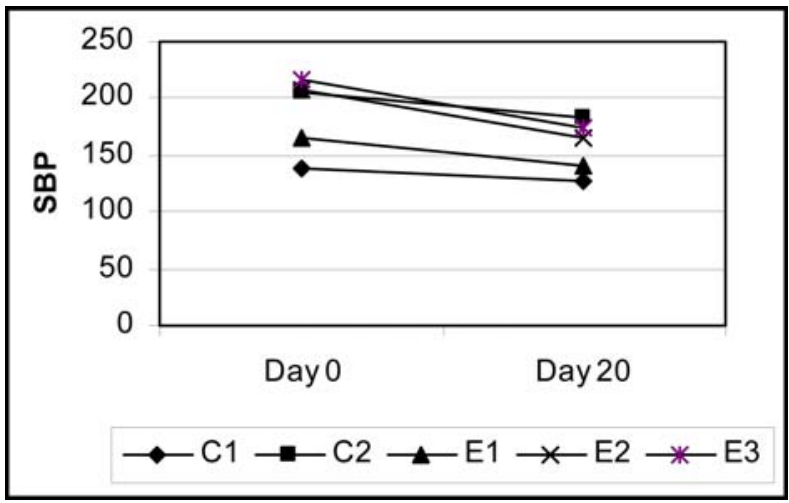

FIGURE 1 - Rats systolic blood pressure (SBP) profile during pregnancy. SBP values decreased significantly in Day 20 compared with Day 0 in all groups $(p<0.001)$ Levels were similar in treated and untreated rats.

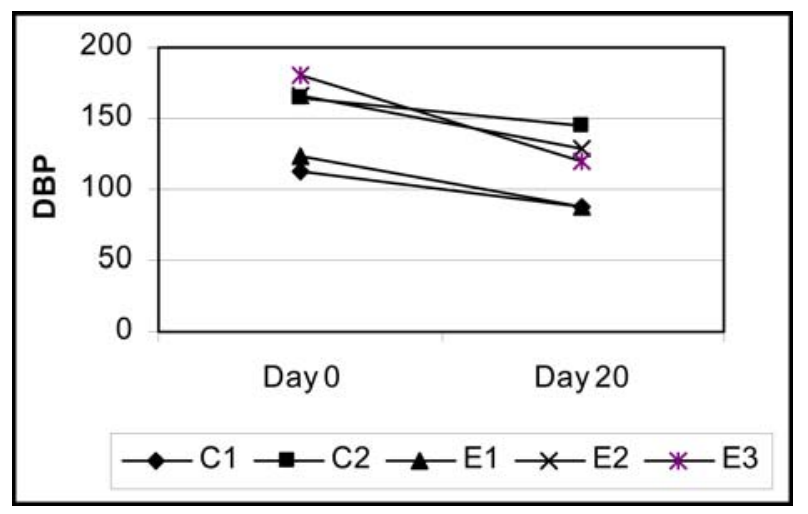

FIGURE 2 - Rats diastolic blood pressure (DBP) profile during pregnancy. DBP values decreased significantly in Day 20 compared with Day 0 in all groups $(\mathrm{p}<0.001)$, except C2. 


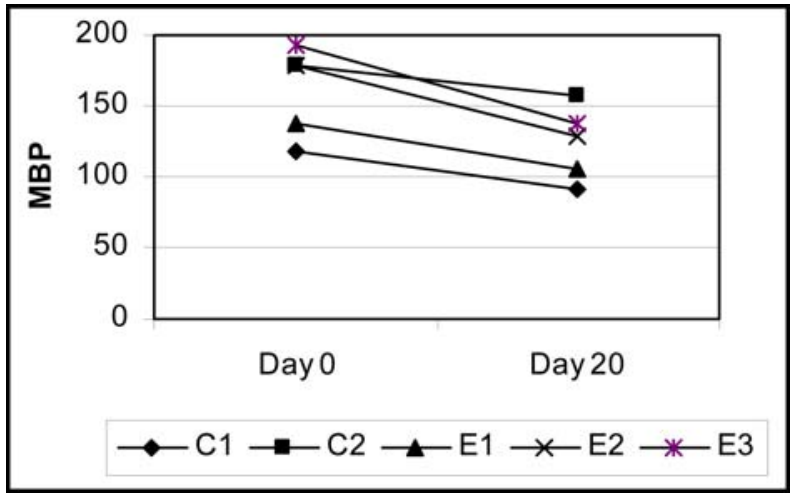

FIGURE 3 - Rats mean blood pressure (MBP) profile during pregnancy. DBP values decreased significantly in Day 20 compared with Day 0 in all groups $(\mathrm{p}<0.001)$, except C2.

Weight

Figure 4 depicts weight variations during pregnancy.

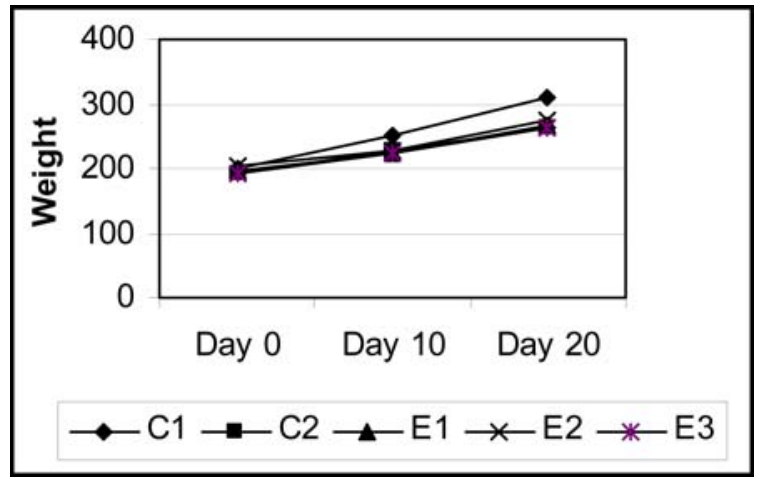

FIGURE 4 - Rats weight profile during pregnancy. There was a significant weight gain during pregnancy (from day 0 to day 20) in all groups. However, there were no significant differences among treated and untreated groups.

\section{Discussion}

Behavior of blood pressure during pregnancy is controversial in rat experimental models. Some data show no effect of pregnancy on blood pressure in the SHR strain ${ }^{15-16}$ whereas others show a significant fall in blood pressure in the same strain ${ }^{17-19}$. Peracoli et al. ${ }^{3}$ found a significant reduction in blood pressure levels in pregnant SHR groups. Blood pressure fall was dependent on the frequency at which blood pressure was measured, suggesting that stress can influence the behavior of blood pressure in experimental animals. In that study, blood pressure was measured in 9 instances. In the present study blood pressure was measured in two occasions (beginning -Day 0 and end of pregnancy - Day 20). Each blood pressure value reported was the mean of five determinations that were taken during the same session. Mean blood pressure in C2 (non-treated SHR) was 178 \pm 17 and 118 \pm 24 in Day 0 and $156 \pm 35$ and $98 \pm 19$ in Day 20, respectively. The apparent drop in mean blood pressure (MBP) values during pregnancy lacked statistical significance in groups Control 1, Control 2 and L-Arginine while a significant Mean blood pressure drop occurred in rats treated with methyldopa $(178 \pm 14$ versus $129 \pm 38, \mathrm{p}<0.01)$ and L-Arginine+Alphamethyldopa ( $192 \pm 19$ versus $137 \pm 26, \mathrm{p}<0.001$ ). Blood pressure levels are known to decrease during pregnancy in rats. There is no clear explanation for this event and a number of hypothesis have been raised, such as the number of fetuses $^{19-20}$, the angiotensin-renin system effect ${ }^{19,21-22}$ and endothelium-derived relaxing factor activity ${ }^{23}$. SBP values were 34\% higher in Group Control 2 rats compared with Group Control 1 ( $\mathrm{p}<0.001)$; Also, SBP in Alpha-methyldopa (34\%) and L-Arginine+Alpha-methyldopa (39\%) groups were higher compared with Group Control $1(\mathrm{p}<0.001)$. No significant differences occurred when comparing mean SBP levels in Group L-Arginine and Group Control 1 rats (Fig. 1). Just handling the rats could cause an increase in blood pressure, as SHR strain shows an exaggerated sympathetic response when submitted to stress ${ }^{24-26}$.

Group Control 1 (non-hypertensive Wistar EPM -1 rats) and Group L-Arginine rats presented similar (no significant difference) systolic and diastolic blood pressure levels at the beginning (Day 0) and the end (Day 20) of pregnancy (Fig. 1$2)$. Decreased mean blood pressure (MBP) levels $(\mathrm{p}<0.001)$ were found when comparing L-arginine treated SLR with untreated SHR groups in Day $20(\mathrm{p}<0.001)$ of pregnancy (Fig. $3)$. The sympathetic antagonist methyldopa is the first-choice hypotensive agent in the treatment of pregnancy-induced hypertension. Podjarny et al. ${ }^{27}$ studied the effects of methyldopa (400 mg/kg/day) and L-arginine (260 mg/kg/day) in forty pregnant Wistar rats pretreated with L-NAME (Nitro L-arginine methyl ester, NO synthase inhibitor, $9-10$ mg/kg/ day) from mid-pregnancy (day 11) through to term and concluded that both methyldopa and L-arginine normalized SBP. Methyldopa or methyldopa+L-arginine treatments during SHR pregnancy failed to provide significant reduction in MBP in the present experiment. This result could be dose-related. Considering that a rat ingests approximately 8-11 ml of drinking water $/ 100 \mathrm{~g}$ body weight/day ${ }^{28}$ it is possible to estimate the amount of L-arginine ingested per each animal. As L-arginine was offered in drinking water ( $2 \%$ solution, $1 \mathrm{ml}=20 \mathrm{mg}$ arginine) the average rat (200g) ingested approximately 16$22 \mathrm{ml}$ of water containing 320-440mg (1600 - $2200 \mathrm{mg} / \mathrm{Kg} /$ day) of L-arginine. Therefore the dose of L-arginine given to LArginine and L-Arginine+Alpha-methyldopa treated rats was 6-8 fold greater than that used by other researchers. ${ }^{27}$ Further studies using L-arginine in different concentrations may clarify this issue. On the other hand, the dose of methydopa used by Podjarny et al. ${ }^{27}$ was 8 - fold greater than the dose employed in the present experiment where rats received methyldopa $66 \mathrm{mg} /$ $\mathrm{kg} /$ day. It is possible that the small dose used in this study was not adequate to provide effective blood pressure reduction in this model.

The greatest weight gain occurred in C1 rats when comparing mean weight of all groups was observed that. SHR treated groups (L-Arginine, Alpha-methyldopa, and LArginine+Alpha-methyldopa) mean weights were not different 
compared with Control 2 (untreated SHR) rats. L-arginine treatment did not alter significantly the weight gain in LArginine treated rats (Fig. 4).

\section{Conclusion}

L-arginine supplementation does not enhance weight gain in pregnant spontaneously hypertensive rats. It is hypothesized that L-arginine oral supplementation may reduce mean blood pressure in spontaneously hypertensive rats.

\section{References}

1. Sibai BM. Diagnosis and management of gestational hypertension and preeclampsia. Obstet Gynecol. 2003;102(1):181-92.

2. Okamoto K, Aoki K. Development of a strain of spontaneously hypertensive rats. Jpn Circ J. 1963;27:282-93.

3. Peracoli JC, Rudge MV, Sartori MS, da Silva Franco RJ. Effects of hypertension on maternal adaptations to pregnancy: experimental study on spontaneously hypertensive rats. Sao Paulo Med J. 2001;119(2):54-8.

4. Racasan S, Braam B, van der Giezen DM, Goldschmeding R, Boer P, Koomans HA, Joles JA. Perinatal L-arginine and antioxidant supplements reduce adult blood pressure in spontaneously hypertensive rats. Hypertension. 2004;44(1):83-8.

5. McCarty R, Kopin IJ. Pregnancy: its effects on blood pressure, heart rate and sympatho-adrenal activity in spontaneously hypertensive rats. Proc Soc Exp Biol Med. 1978;158:242-4.

6. Yamada N, Kido K, Tamai T, Mukai M, Hayashi S. Hypertensive effects on pregnancy in spontaneously hypertensive rats (SHR) and stroke-prone SHR (SHRSP). Int J Biol Res Pregnancy. 1981;2:80.

7. Zamorano B, Terragno A, McGiff JC, Terragno NA. A prostaglandin mechanism may contribute to the regulation of blood pressure in spontaneously hypertensive rats during pregnancy. Adv Prostagl Thromb Res. 1980;7:807-10.

8. Lindheimer MD, Katz AI, Koeppen BM, Ordóñez NG, Oparil S. Kidney function and sodium handling in the pregnant spontaneously hypertensive rat. Hypertension. 1983;5:498-506.

9. Ahokas RA, Sibai BM. The relationship between experimentally determined litter size and maternal blood pressure in spontaneously hypertensive rats. Am J Obstet Gynecol. 1990;162:841-7.

10. Sanders BJ, Gray MJ. Early environmental influences can attenuate the blood pressure response to acute stress in borderline hypertensive rats. Physiol Behavior. 1997;61:749-54.

11. Coelho EB, Ballejo G, Salgado MCO. Nitric oxide blunts sympathetic response of pregnant normotensive and hypertensive rat arteries. Hypertension. 1997;30:585-8.

12. Seremak-Mrozikiewicz A, Drews K. Methyldopa in therapy of hypertension in pregnant women. Ginekol Pol. 2004;75(2):160-5.

13. Maeda T, Wakasawa T, Shima Y, Tsuboi I, Aizawa S, Tamai I. Role of polyamines derived from arginine in differentiation and proliferation of human blood cells. Biol Pharm Bull. 2006;29(2):234-9.

14. International Guiding Principles for Biomedical Research involving animals. Council for International Organization of Medical Sciences (CIOMS). WHO Chronicle. 1985;39(21):51-6.

15. McCarty R, Kopin IJ. Pregnancy: its effects on blood pressure, heart rate and sympatho-adrenal activity in spontaneously hypertensive rats. Proc Soc Exp Biol Med. 1978;158:242-4.

16. Yamada N, Kido K, Tamai T, Mukai M, Hayashi S. Hypertensive effects on pregnancy in spontaneously hypertensive rats (SHR) and stroke-prone SHR (SHRSP). Int J Biol Res Pregnancy. 1981;2:80.

17. Ahokas RA, Sibai BM. The relationship between experimentally determined litter size and maternal blood pressure in spontaneously hypertensive rats. Am J Obstet Gynecol. 1990;162:841-7.

18. Zamorano B, Terragno A, McGiff JC, Terragno NA. A prostaglandin mechanism may contribute to the regulation of blood pressure in spontaneously hypertensive rats during pregnancy. Adv Prostaglandin Thromboxane Res. 1980;7:807-10.

19. Lindheimer MD, Katz AI, Koeppen BM, Ordóñez NG, Oparil S. Kidney function and sodium handling in the pregnant spontaneously hypertensive rat. Hypertension. 1983;5:498-506.

20. Ahokas RA, Reynolds SL, Anderson GD, Lipshitz J. Uteroplacental blood flow in the hypertensive, term pregnant, spontaneously hypertensive rat. Am J Obstet Gynecol. 1987; 156:1010-5.

21. Berssenbrugge AD, Goodfriend TL, Ball DL, Rankin HG. The effect of pregnancy on the angiotensin II pressor response in the rabbit. Am J Obstet Gynecol. 1980; 136:762-7.

22. Mulvany MJ. Do resistance vessel abnormalities contribute to the elevated blood pressure of spontaneously hypertensive rats? A review of some of the evidence. Blood Vessels. 1983; 20:1-22.

23. Ahokas RA, Mercer BM, Sibai BM. Enhanced endotheliumderived relaxing factor activity in pregnant, spontaneously hypertensive rats. Am J Obstet Gynecol. 1991;165:801-7.

24. Chiueh CC, Kopin IJ. Hyperresponsivity of spontaneously hypertensive rat to indirect measurement of blood pressure. Am J Physiol. 1978; 234:H690-5.

25. Share L, Crofton J. Sympatho-adrenal hyperreactivity to footshock stress but not to cold exposure in SHR. Physiol Behavior. 1981;26:85-9.

26. Picotti GB, Carruba MO, Ravazzani C, Bandiolotti GP, Da Prada M. Plasma cathecolamine concentrations in normotensive and in spontaneously hypertensive rats under basal conditions in spontaneously hypertensive rats under basal conditions during cold exposure. Life Sci. 1982;31:2137-43.

27. Podjarny E, Benchetrit S, Katz B, Green J, Bernheim J. Effect of methyldopa on renal function in rats with L-NAMEinduced hypertension in pregnancy. Nephron. 2001; 88(4):354-9.

28. Pass D, Freeth G. The rat. ANZCCART News. 1993; 6(4):1-4. 


\section{Correspondence:}

Dr. José Ricardo Sousa Ayres de Moura

Rua Coronel Linhares, 442/1500

60170-240 Fortaleza-CE Brazil

Phone: (55 85)3264-2241

ayresdemoura@hotmail.com
Conflict of interest: none

Financial source:

Program of Teaching Qualification and Technical Improvement (CAPES)

Federal University of Ceará

Received: January 10, 2006

Review: February 14, 2006

Accepted: March 15, 2006

\title{
How to cite this article:
}

Moura JRSA, Sass N, Guimarães SB, Vasconcelos PRL, Mattar R, Kulay Jr L. Effects of L-arginine oral supplements in pregnant spontaneously hypertensive rats. Acta Cir Bras. [serial on the Internet] 2006 July-Aug;21(4). Available from URL: http://www.scielo.br/acb

\section{O 7th International Gastric Cancer Congress será realizado de 9 a 12 de Maio de 2007 em São Paulo}

\author{
Dr. Joaquim Gama-Rodrigues \\ Presidente, 7th IGCC \\ Dr. Paulo Kassab
}

Secretário Geral, 7th IGCC

INFORMAÇÕES

Paola Graziella Gandolfo

Meeting Eventos - Secretária Executiva 7th IGCC

$55 \quad 11 \quad 3849-0379$

www.meetingeventos.com.br 